\title{
The Effectiveness Of Civil Servant Candidate (PPNS) In Enforcement of Spatial Planning Laws
}

\author{
Iin Parlina*) and Siti Rodhiyah Dwi Rodhiyah**) \\ $\left.{ }^{*}\right)$ Master of Law Program, Faculty of Law Universitas Islam Sultan Agung email \\ iparlina82@yahoo.co.id \\ $\left.{ }^{* *}\right)$ Faculty of Law Universitas Islam Sultan Agung
}

\begin{abstract}
This study aims to describe the effectiveness of PPNS in enforcing the Spatial Planning Law. In line with the research objectives, in this study using normative juridical research methods, it is concluded: (1) The issuance of Act No. 11 of 2020 concerning Job Creation, has changed the content of Act No. 26 of 2007 concerning Spatial Planning. The legal basis for implementing spatial planning nationally, needs to be synergized in one Government Regulation. PP 21 of 2021 concerning the Implementation of Spatial Planning, integrates various cross-sectoral, cross-regional, and cross-stakeholder interests which are manifested in the preparation of Spatial Plans. Creating conditions for laws and regulations in the field of Spatial Planning that support the investment climate and ease of doing business. Violation of Act No. 11 of 2020, carried out by Civil Servant Investigators ("PPNS"), which are investigators from civil servants to investigate certain criminal acts. The effectiveness of the application of the law for violations of spatial planning, is highly dependent on the legal instruments of each Ministry or government agency/institution. Strengthening legal instruments (both regulations and institutional investigators for PPNS) needs to be taken seriously, because of the lack of legal application for violators of spatial planning. (2) The implementation of spatial planning is still not in accordance with the existing laws and regulations.
\end{abstract}

Keywords: Effectiveness; Enforcement; Spatial Planning Laws.

\section{Introduction}

Indonesia is a very large country consisting of 17,504 islands, located in the Pacific Ocean and Indian Ocean, so Indonesia must have good spatial planning. The unitary territory of the Republic of Indonesia consists of sea space, land space and air space which are protected and managed for the prosperity of the people. Indonesia, as mandated in Article 33 Paragraph (3) of the 1945 Constitution of the Republic of Indonesia which reads 'Oil and Natural Gas as strategic natural resources contained in the earth The Indonesian Mining Law Area is a national asset controlled by the State and used for as much as possible for the people of Indonesia". To realize the harmony of the natural environment in the territory of Indonesia. The government established Act No. 21 of 2021 concerning Spatial Planning which is a derivative of Act No. 11 of 2020 concerning Job Creation in order to realize the integrated use of natural resources and provide protection for spatial functions and prevention of negative impacts on the environment.

The concept of spatial planning in Act No. 21 of 2021 concerning Spatial Planning has been prepared regarding the designation of each space, space utilization and space control if the use of the space is not in accordance with the plan. However, the problem that often occurs is whether there is harmony between 
the rules and their implementation or not. Likewise, in spatial planning, the current factual conditions illustrate that the spatial planning provisions that are prepared are not in line with their implementation land such as an example of protected land into cultivation. ${ }^{1}$

In 2020, based on the results of an audit by the Ministry of ATR/BPN, there were 6,621 locations in Indonesia that were found to be in violation of spatial use violations, and 5,286 locations were found in Java Island. ${ }^{2}$. If this continues, violations of spatial use will certainly have a negative impact on the enforcement of spatial planning law in the context of realizing spatial order.

The above fact illustrates that the existence of Act No. 26 of 2016 which has been amended by Act No. 21 of 2021 concerning Spatial Planning has not been able to be used as the spirit of improving spatial planning in Indonesia. If the existing legal instruments have not been able to achieve spatial planning improvements, it will certainly have an impact on the effectiveness of law enforcement.

Based on the above background, this study aims to identify and analyze solutions to achieve the effectiveness of law enforcement in spatial planning in Indonesia.

\section{Research Methods}

This study uses a normative research method, meaning that it is through a statutory approach. The statutory approach is carried out by reviewing all laws and regulations related to the legal issues being handled. By using primary legal materials and secondary legal materials. The collection of legal materials is carried out through a literature study, which begins with classifying legal materials, by systematically reading the available legal materials, which are used as guidelines to answer the formulation of existing problems, and in conducting the analysis the authors use the interpretation method, namely research methods that starting from the opinions that exist in these problems are interpreted through language, legal or systematic interpretation of the issues to be discussed.

\section{Results and Discussion}

\subsection{The Effectiveness of Imposing Sanctions in Spatial Planning in Indonesia}

The effectiveness of the imposition of sanctions in spatial planning in Indonesia can be seen from the problems regarding spatial planning that occur today, namely the existence of weak law enforcement, especially in the imposition of sanctions. Law enforcement in the imposition of sanctions against the Act is divided into three forms of sanctions, namely administrative sanctions, civil sanctions and criminal sanctions at a glance the regulation of these sanctions will be able to control the use of space that is not in accordance with the spatial plan that has been determined. In the field, spatial planning is carried out to fulfill partial

\footnotetext{
$1 \mathrm{Ni}$ Putu Eriska Wasista Dewi et al, Pengenaan Sanksi Dalam Penataan Ruang di Indonesia, https://download.garuda.risdekdikti.go.id, accessed on 12 July 2021

2 https://atr.go.id
} 
sectoral objectives. This causes tremendous chaos in the spatial arrangement of an area. $^{3}$

In PP No. 21 of 2021, the imposition of sanctions for violators who commit violations in the implementation of spatial planning will only be subject to administrative sanctions, no civil sanctions or criminal sanctions are regulated. This shows that there is a legal vacuum regarding the imposition of sanctions regulated in the PP. The imposition of sanctions in the Spatial Planning Law which is heavy in nature will not be useful, if the supervision and enforcement of the law does not go well.

Sanctions imposed for violations of spatial planning based on Act No. 26 of 2007 concerning Spatial Planning, Act No. 11 of 2020 concerning Job Creation, Government Regulation (PP) Number 21 of 2021 concerning the Implementation of Spatial Planning and Regional Regulations concerning Spatial Planning are administrative sanctions from the lightest such as giving written warnings, cancellation of permits, demolition to severe sanctions in the form of environmental restoration. As it is known that humans always interact with the environment in their lives. If someone does not understand and appreciate the importance of the environment for survival and life, then someone will tend to be indifferent to the environment ${ }^{4}$.

Permits are the implementation of regulations in concrete terms, functioning as the spearhead of legal instruments as directors, engineers, and designers of a just and prosperous society that is incarnated. ${ }^{5}$ Therefore, space utilization permits issued by the Government (both central government, provincial government and district/city governments) must be in accordance with their respective authorities.

On the other hand, the lack of supervision and control has resulted in spatial planning violations. The government, especially the regional government, is not able to provide human resources capable of supervising and controlling in the event of spatial irregularities. Spatial planning violations also occur due to the absence of synchronization of permits among agencies as a result of a lack of understanding of the duties and functions of a government and also the absence of spatial planning guidelines as guidelines in issuing permits.

Likewise, the licensing procedure which is complicated, slow and has high costs encourages the community to carry out various ways of building without a permit, which are not in accordance with the spatial plan. In addition, a crucial national problem is the attitude of government officials who are corrupt, so that many officers who are entrusted with the responsibility for spatial planning have a corrupt mentality. They consciously manipulate the spatial plan through wrong

\footnotetext{
${ }^{3}$ Muhar Junef, Penegakkan Hukum Dalam Rangka Penataan Ruang Guna Mewujudkan Pembangunan Berkelanjutan, (https://ejournal.balitbangham.go.id, accessed on. 12 July 2021

4 Solikun Ni'am, Akhmad Khisni and Lathifah Hanim, Law To The Forester of Land And Land Combustion In Blora Regency, Jurnal Daulat Hukum Volume 3 Issue 2, June 2020 ISSN: 2614-560X accessed 12 July 2021

5 Hasni, Hukum Penataan Ruang dan Penatagunaan Tanah, Dalam Konteks UUPA, UUPR, UUPLH, (Jakarta: Rajawali Press, 2013), p. 13.
} 
permits, even this is done by the regional head. ${ }^{6}$ Various ways are carried out, among others, by manipulating the requested location data by changing the coordinates of the measured situation, manipulating the issued permits by changing the designation, issuing permits that are not in accordance with the blueprint of the spatial plan and so on for problematic locations. Likewise, the supervisory apparatus deliberately allows various kinds of violations to occur in the hope of obtaining various rewards. This then causes injustice in urban planning for the community due to manipulations carried out by unscrupulous government officials.

Due to spatial planning violations or irregularities, it is necessary to impose sanctions, as one of the efforts to control space utilization. According to Philipus $\mathrm{M}$ Hadjon, the placement of sanctions in a rule of law is a very important closing part in every statutory regulation, including administrative law rules. In general, there is no point in including legal rules regarding obligations or prohibitions for citizens in the legal regulations in the field of state administration, when the rules regarding behavior that cannot be strictly enforced by government officials or institutions/agencies or officials authorized for it ${ }^{7}$.

Civil Servant Investigator $(P P N S)$ is one of the important instruments in the enforcement of Law (UU) no. 26/2007 on Spatial Planning (UUPR). PPNS has special authority as investigators to assist investigators of the Indonesian National Police in realizing spatial order at all levels of government administration and public life. ${ }^{8}$

The existence of PPNS institutions in each province and district/city is nothing but to strengthen the framework of regional autonomy, in terms of carrying out the authority to administer spatial planning, both provincial and district/city governments. In addition, the existence of PPNS institutions is also in the context of carrying out regulatory, coaching, implementation and monitoring activities as well as law enforcement. ${ }^{9}$

\subsection{PPNS Existence in Law Enforcement}

There are several laws and regulations governing the existence of PPNS, including Article 6 paragraph (1) letter b of the Criminal Procedure Code which states that: "investigators are certain civil servant officials who are given special authority by law." regulated in government regulations are harmonized and balanced with the position and rank of public prosecutors and judges of public

'Ismail Zubir, "Spatial Deviations", KALPATARU, (https://imazu.wordpress.com/2008/01/09/aberrations-tata-ruang/) accessed 19 June 2021).

\footnotetext{
7 Philipus M Hadjon, Pengantar Hukum Administrasi Indonesia, (Yogyakarta: Gadjah Mada University Press, 2002), p. 245, as quoted by Bahder Johan Nasution, "Upaya Penerapan Sanksi Administratif Dan Perizinan Sebagai Pembatasan Terhadap Kebebasan Bertindak", (in Jurnal Ilmu Syariah dan Hukum Asy Syir'ah, Vol. 48, No. 1, June 2014), p. 217

${ }^{8}$ Gery Andika Pinatik, Kedudukan Penyidik Pegawai Negeri sipil (PPNS) Daerah dalam Penegakkan Hukum Tindak Pidana Pelanggaran Tata Ruang (https://ejournal.unsrat.ac.id, accessed on 12 July 2021)

9 Sodikin, Eksistensi Penyidik Pegawai Negeri Sipil (PPNS) Dalam Penegakkan Hukum terhadaf pelanggaran Tata Ruang (https://rechtvinding.bphn.go.id accessed 12 July 2021)
} 
courts. Article 1 number 11 of Act No. 2 of 2002 concerning the Indonesian National Police also explains the existence of PPNS, namely:

Furthermore, in Act No. 23 of 2014 concerning Regional Government, especially in Article 257 of Act No. 23 of 2014 concerning Regional Government, it is stated that there are PPNS, namely:

(1) An investigation into a violation of the provisions of the Regional Regulation is carried out by the investigating officer in accordance with the provisions of the legislation.

(2) In addition to the investigating officer as referred to in paragraph (1), civil servant investigators may be appointed who are assigned the task of investigating violations of the provisions of the Regional Regulation in accordance with the provisions of the legislation.

(3) The civil servant investigator as referred to in paragraph (2) shall submit the results of the investigation to the public prosecutor and coordinate with the local police investigator.

(4) The prosecution of violations of the provisions of the Regional Regulation is carried out by the public prosecutor in accordance with the provisions of the legislation. Act No. 23 of 2014 has provided space for the establishment of PPNS which are specifically placed in the regions and given the task of conducting investigations into the possibility of criminal acts as regulated in a regional regulation.

More specific provisions governing PPNS in the field of spatial planning are regulated in the Regulation of the Minister of Public Works Number 13/PRT/M/2009 concerning Investigators of Civil Servants of Spatial Planning. According to the Ministerial Regulation, PPNS for Spatial Planning are certain Civil Servants within the Directorate General of Spatial Planning at the Ministry of Public Works, certain Civil Servants in the Provincial Government and Regency/Municipal Governments in charge of spatial planning in the regions who carry out the duties, functions and authority in accordance with the provisions of Article 6 paragraph (1) letter b of the Criminal Procedure Code and Article 68 paragraph (1) of Act No. 26 of 2007 concerning Spatial Planning.

The granting of the authority to carry out investigative duties to PPNS facilitates the disclosure of a crime given the many obstacles faced by the police in conducting investigations, such as the quality and quantity of human resources, supporting infrastructure, and budget.

In reality, PPNS also experienced the same thing, especially regarding human resources because of the absence of good guidance, limited budget and no good coordination between the Polri investigatory agencies and PPNS, unclear work programs and the institutional factors of $P P N S$ itself which were not there is. Article 68 paragraph (1) UUPR jo. Regulation of the Minister of Public Works Number 13/PRT/M/2009 concerning Civil Servant Investigators of Spatial Planning, regulates the existence of Civil Servant Investigators as investigators in the event of violations in the field of spatial planning.

The legal basis for the appointment of PPNS is the Minister of Law and Human Rights Regulation No. M.HH.01.AH.09.01 YEAR 2011 Regarding Procedures for Appointment, Dismissal, Mutation, and Taking Oaths or Promises of Civil Servant 
Investigating Officers, and the Form, Size, Color, Format, and Issuance of Identity Cards for Civil Servant Investigators. The provisions in the regulation of the Minister of Law and Human Rights stipulate the requirements to become PPNS within the respective agencies, including in the spatial planning agency environment. The appointment of PPNS is carried out by the Minister of Law and Human Rights, but the authority of the appointment is at the suggestion of the leadership of the ministry or other government institutions that require the existence of PPNS.

\subsection{Law Enforcement Efforts by PPNS}

Law enforcement against violations or irregularities in spatial use is one of the important pillars to realize orderly spatial planning. According to Bagir Manan, the success of a statutory regulation depends on its implementation and enforcement, if law enforcement does not go well, the statutory regulations however perfect do not or lack meaning in accordance with their objectives, law enforcement is a dynamist of legislation. ${ }^{10}$. The existence of PPNS Spatial Planning at the central, provincial, and district/city levels is needed in the context of law enforcement for orderly spatial planning to encourage every effort to utilize space in accordance with the National Spatial Planning (RT/RW) as required in the Preamble to the 1945 Constitution.

In principle, the spatial planning system is divided into 3 (three) parts, namely: (1) planning; (2) management and utilization of space; and (3) spatial management and control. In the context of implementing transparent, effective, safe, comfortable, productive, and sustainable spatial planning, the presence of rules and law enforcement agencies in the field of spatial planning is very necessary. PPNS as one of the pillars of the apparatus in law enforcement in the field of spatial planning requires legality in the institutional structure of the criminal justice system, so that the community obtains legal guarantees and certainty. Law enforcement and law enforcement have not been carried out in accordance with the principles of justice and truth ${ }^{11}$.

Efforts to enforce the law by PPNS-PR will certainly encounter various obstacles in carrying out its authority as specified in the legislation, including:

- There are no adequate instruments for controlling the use of spatial planning in the regions (only a few provinces and regencies/cities have ratified the RT/RW). Due to inadequate spatial planning products, PPNS-PR in carrying out their duties in law enforcement is experiencing difficulties.

- (2). The PPNS-PR staffing and institutional system is appointed by the government, at the provincial level it is appointed by the governor, while at the district/city level by the regent/mayor. This staffing appointment system is included in the career path and the rank is determined by the respective regional heads, whose existence is not proportional to the area of their territory.

\footnotetext{
10 Bagir Manan., "Pembinaan Hukum Nasional”, (Common Lecturing at Faculty of Law, Universitas Padjadjaran, Bandung, August 18, 2001), p. 8

11Erman Rajagukguk., "Perlu Pembaharuan Hukum dan Profesi Hukum", (Inaugural Speech as Professor of Law, Voice of Reform), p. 11
} 
- (3). The unavailability of institutional work units that specifically accommodate PPNS-PR in carrying out the duties and functions of PPNS-PR, which are still scattered in various Regional Work Units of each, which are already burdened with the main tasks in their respective units. This has resulted in the coaching and development of PPNS-PR capabilities for which there is no clear plan and work program.

- (4). Legal protection tools for PPNS-PR are not available, because the laws and regulations that provide for the existence of $P P N S$ in the field of spatial planning law enforcement do not provide protection. Because there is no legal protection device for PPNS-PR, this should be a concern of the government because PPNS$P R$ in carrying out law enforcement duties is always related to vertical and horizontal conflicts, namely problems that exist in the community and problems that originate from government policies, which will then threaten the position of the government as a civil servant and civil servant investigator in the field of spatial planning.

- (5). There is overlapping authority in law enforcement in the field of spatial planning. In addition to PPNS-PR, there are also several agencies or institutions that can carry out curbs on violations of spatial use, namely the Regional Spatial Planning Coordinating Board (BKPRD), permit issuing agencies, as well as other agencies or institutions in charge of controlling.

\section{Closing}

The implementation of spatial planning is still not in accordance with the existing laws and regulations. PPNS-PR institutions that are given the authority to carry out law enforcement, especially in the case of spatial planning violations, cannot do their best because of their existence problems in the law enforcement system in the field of spatial planning. Therefore, to strengthen the existence of PPNS in the field of spatial planning, several things need to be done including: Making a more detailed set of laws and regulations that show the institutional and employment status of PPNSPR definitively, so that its existence can be at the center or in the regions; Adequate facilities (facilities and infrastructure) in order to carry out their authority and clear budget support in the context of law enforcement against spatial planning violations; The need to prepare a planned work program in law enforcement efforts; The need to prepare professional spatial planning PPNS personnel/members with the provision of well-established and quality education and coaching; and Establish strategic partnerships with the police, prosecutors, judicial institutions, related agencies.

\section{References}

\section{Journal}

[1] Muhar Junef, Penegakkan Hukum Dalam Rangka Penataan Ruang Guna Mewujudkan Pembangunan Berkelanjutan, (https://ejournal.balitbangham.go.id, accessed on. 12 July 2021 
[2] Ni Putu Eriska Wasista Dewi et al, Pengenaan Sanksi Dalam Penataan Ruang di Indonesia, https://download.garuda.risdekdikti.go.id, accessed on 12 July 2021

[3] Philipus M Hadjon, Pengantar Hukum Administrasi Indonesia, (Yogyakarta: Gadjah Mada University Press, 2002), p. 245, as quoted by Bahder Johan Nasution, "Upaya Penerapan Sanksi Administratif Dan Perizinan Sebagai Pembatasan Terhadap Kebebasan Bertindak", (in Jurnal Ilmu Syariah dan Hukum Asy Syir'ah, Vol. 48, No. 1, June 2014)

[4] Solikun Ni'am, Akhmad Khisni and Lathifah Hanim, The Implementation of Criminal Law To The Forester Of Land And Land Combustion In Blora Regency, Jurnal Daulat Hukum Volume 3 Issue 2, June 2020 ISSN: 2614-560X accessed 12 July 2021

\section{Books}

[1] Bagir Manan., "Pembinaan Hukum Nasional”, (Common Lecturing at Faculty of Law, Universitas Padjadjaran, Bandung, August 18, 2001)

[2] Erman Rajagukguk., "Perlu Pembaharuan Hukum dan Profesi Hukum", (Inaugural Speech as Professor of Law, Voice of Reform)

[3] Gery Andika Pinatik, Kedudukan Penyidik Pegawai Negeri sipil (PPNS) Daerah dalam Penegakkan Hukum Tindak Pidana Pelanggaran Tata Ruang (https://ejournal.unsrat.ac.id, accessed on 12 July 2021)

[4] Hasni, Hukum Penataan Ruang dan Penatagunaan Tanah, Dalam Konteks UUPA, UUPR, UUPLH, (Jakarta: Rajawali Press, 2013)

[5] Ismail Zubir, "Spatial Deviations", KALPATARU, (https://imazu.wordpress.com/2008/01/09/aberrations-tata-ruang/) accessed 19 June 2021).

[6] Sodikin, Eksistensi Penyidik Pegawai Negeri Sipil (PPNS) Dalam Penegakkan Hukum terhadaf pelanggaran Tata Ruang (https://rechtvinding.bphn.go.id accessed 12 July 2021)

\section{Regulation}

[1] Constitution of the Republic of Indonesia of 1945

[2] Act No. 26 of 2007 concerning Spatial Planning in conjunction with Act No. 21 of 2021

[3] Act No. 23 of 2014 concerning Regional Government

[4] Act No. 2 of 2002 concerning the Indonesian National Police

[5] Regulation of the Minister of Public Works No. 13/PRT/M/2009 concerning Investigators of Civil Servants of Spatial Planning. Regulation of the Minister of Law and Human Rights No.M.HH.01. AH.09.01 of 2011 concerning Procedures for Appointment, Dismissal, Transfer, and Taking Oaths or Promises of Civil Servant Investigating Officers, and the Form, Size, Color, Format, and Issuance of Identity Cards for Civil Servant Investigating Officers. 